\title{
Effectiveness of Punica granatum Juice in Ameliorating Oxidative Damage and Ultrastructural Changes in Paneth Cells of Rat Intestine
}

\author{
Eltahawy $\mathrm{N}^{1}$, Abunour $\mathrm{S}^{2,}$, Elsonbaty $\mathrm{S}^{3}$ \\ ${ }^{1}$ Radiation Biology, ${ }^{2}$ Health Research and ${ }^{3}$ Radiation Microbiology Departments, National Center for Radiation \\ Research and Technology (NCRRT), Atomic Energy Authority, Cairo, Egypt
}

\begin{abstract}
Introduction: Radiation therapy for tumor management is limited due to damage and functional failure of small intestine. The purpose of this study is to evaluate the role of pomegranate fruit juice (PJ) in radiation-induced biochemical and structure disorders in the small intestine.

Materials and methods: Male albino rats were exposed to gamma radiation at a dose of $2 \mathrm{~Gy} /$ week up to $8 G y$. $P J$ was administered to rats via gavages before and during the irradiation period and were sacrificed one day after the last radiation dose.
\end{abstract}

Results: Biochemical analysis in the ileum of irradiated rats showed decreases of superoxide dismutase, catalase and glutathione peroxidase activities, and glutathione content, associated with an increases of thiobarbituric acid reactive substances, protein carbonyls and advanced oxidation protein products levels, and $T N F-\alpha$ level. Flow cytometry analysis showed significant alterations in ileum cell cycle and increase in apoptotic cell percentage. Ultrastructural studies showed marked intestinal injury in the ileum of irradiated rats and severe damage in Paneth cells at the sites of bacterial translocation in the crypt of lumens. Supplementations of rats with PJ significantly attenuated oxidative stress, ameliorated antioxidant parameters and ultrastructural alterations in Paneth cells and protects it from bacterial invasion.

Conclusion: These results imply that PJ showed potent antioxidant activity may protect small intestine from radiation-induced oxidative damage.

Key words: Small intestine, Paneth cells, ionizing radiation, oxidative stress, cell cycle, TNF- $\alpha$, ultrastructural studies.

\section{Introduction}

Radiation-related disorders are one of the challenging current health problems with far reaching medical, social and economic consequences. Radiation therapy is an essential therapeutic modality in the management of a wide variety of tumors, but its immediate and delayed side effects on normal tissues as gastrointestinal epithelium and bone marrow progenitor cells, both of which are critically important for survival, limit the effectiveness of the therapy.

Radiation damage is largely caused by the overproduction of reactive oxygen species (ROS), including superoxide anion $\left(\mathrm{O}^{-}{ }^{-}\right)$, hydroxyl radical $\left({ }^{\circ} \mathrm{OH}\right)$, and hydrogen peroxide $\left(\mathrm{H}_{2} \mathrm{O}_{2}\right)$, that overwhelm the levels of antioxidants, resulting in oxidative stress. The most important consequences of oxidative stress are lipid peroxidation, protein oxidation, and depletion of antioxidant elements. If these damages are irreparable, then injury, mutagenesis, carcinogenesis, accelerated senescence and cell death can occur (1).

Regarding the small intestine, acute morphological changes are associated with motor dysfunction (2). Exposure to ionizing radiation induces oxidative stress, induce sloughing villi, ulcers, and ruptured goblet cells, shrinkage of submucosa layers, more fibers and fibroblast $(3,4 \& 5)$. Death may occur as a direct consequence of the damage of epithelial crypt cells and followed denudation of villi leading to fluid and electrolyte imbalance, bacteremia and endotoxemia, endothelial dysfunctions (6). Accompanied by production and release proinflammatory cytokines such as TNF- $\alpha$ and IL-1 $\beta$ (7).

Paneth cells secrete granules containing a variety of peptides and proteins with known host defense functions as $\alpha$-defensins (or cryptdins), cysteine-rich polypeptides which have a broad range of antimicrobial activity (8\&9). Trillions of diverse microbes colonize the intestine that provides essential functions for host survival. In addition to digestion, the gut microbial regulate caloric storage, metabolize xenobiotics, modify the immune system, and regulate postnatal gut development including a network of capillaries in the mesenchyme of the small intestinal villi (10\&11). In this line, (12) suggested that activation of Paneth cells can be a part of local regulatory mechanism and /or innate defense response in the irradiated intestine that can be essential during the post radiation exposure period.

Pomegranate fruit possesses potent antioxidant activity and free radical scavenging capability. It is a rich source of two types of polyphenolic compounds: anthocyanins and hydrolysable tannins, responsible for 
antioxidant activity $(13,14 \& 15)$. Pomegranate have antibacterial, anti-inflammatory (16\&17) and antimutagenic activity (18). In view of these considerations, the main objective of the present study is to evaluate the efficacy of $\mathrm{PJ}$ in modulating post irradiation alterations in biochemical and ultrastructure damages of ileum.

\section{Materials and Methods}

All animal procedures were performed in accordance with the Ethics Committee of the National Research Center and in accordance with the recommendations for the proper care and use of laboratory animals (NIH publication No. 85-23, revised 1985).

Irradiation was performed through the use of a Canadian Gamma cell-40 $\left({ }^{137} \mathrm{Cs}\right)$ at the National Center for Radiation Research and Technology (NCRRT) (Cairo, Egypt). The dose rate was 0.5Gy/minute. Pomegranate juice (PJ) (Punica granatum L, Punicaceae) was purchased from Life Extension Company, USA. Rats received $1 \mathrm{ml} / \mathrm{Kg}$ body wt/day, by gavages (19).

Matured male Wistar albino rats (130-140grams) used for this experimental study were purchased from the Egyptian Holding Company for Biological Products and Vaccines (Cairo, Egypt). Animals were housed under standard conditions of light and temperature and allowed free access to standard pellet diet and tap water. Animals were randomly divided into four groups $(n=8)$. Control group: animals neither exposed to radiation nor treated with PJ. PJ group: Animals received PJ ( $1 \mathrm{ml} / \mathrm{K}$ g body wt), by gavages, daily for 28 days. Irradiation group: Animals whole body exposed to $2 \mathrm{~Gy} /$ week up to $8 \mathrm{~Gy}$. PJ+irradiation group: animals received PJ $(1 \mathrm{ml} / \mathrm{Kg} /$ daily $) 5$ days before irradiation and during the period of radiation exposure.

Animals were anesthetized and sacrificed 24 hour post last dose of irradiation. The intestine was stripped of mesenteric and vascular connections and removed from the peritoneum. The lumen was flushed with ice-cold saline to clear intestinal contents. The segments of ileums were collected sequentially at equivalent sites of each rat, rapidly excised for histological, ultrastructure and flow cytometry investigations. A small portion of small intestine (ileum) was removed and frozen at $-80^{\circ} \mathrm{C}$ until biochemical assay.

\section{Biochemical analysis:}

Weighted segment of intestinal specimens (ileum) was homogenized in phosphate buffer saline (10\% $\mathrm{w} / \mathrm{v}$ ) and used for various biochemical analyses. GPx, SOD and CAT activities were determined according to $(20,21 \& 22)$ respectively. Reduced glutathione (GSH) was estimated (23). The extent of lipid peroxidation was assayed by the measurement of TBARS (24). Protein contents, was determined (25). Determination of AOPPs was based on spectrophotometric detection (26) and protein-bound carbonyls (CO) (27). Evaluation of tumor necrosis factor- alpha (TNF- $\alpha$ ) in rat small intestine cells homogenate was measured (28), using the "Assay Max Rat TNF-alpha ELISA kit of murine monoclonal antibody". (ASSAYPRO, 41 Triad South Drive St. Charles, MO 63394, USA). Data was analyzed using 990win6 software for DV990BV4 microplate reader, GIO DE VITA, Roma, Italy.

\section{Evaluation of apoptosis and cell cycle analysis by flow cytometry:}

Flow cytometric analysis was performed for cell cycle analysis and evaluation of apoptosis. Small intestine ileums were cut into small pieces and fixed in 70\% ethanol in phosphate buffer saline (PBS) for $1 \mathrm{~h}$ on ice, incubated with $50 \mu \mathrm{g} / \mathrm{ml}$ RNase A at $37^{\circ} \mathrm{C}$ overnight, stained with $50 \mu \mathrm{g} / \mathrm{ml}$ propidium iodide and subjected to flow cytometric analysis using FACS Calibur. Cells were then analyzed for green (FITC, indicating DNA fragmentation detection) and (PI, allowing DNA quantification) red fluorescence by flow cytometry using a Becton Dickinson ${ }^{\circledR}$ FAC Star Plus flow cytometer. Apoptotic cells were identified in a DNA histogram as a subG1 hypodiploid population (29).

\section{Transmission electron microscope study:}

Intestinal ileums were dissected out carefully and very small pieces were fixed in $2.5 \%$ glutaraldehyde overnight, post fixed in $1 \%$ osmium tetraoxide, dehydrated in graduated series of ethanol and embedded in Spurr's epoxy resin. Ultrathin sections $(80-90 \mathrm{~nm})$ were stained with uranyl acetate and lead citrate (30). The sections were examined with a JEOL electron microscope (JEM-100 CX) at $80 \mathrm{KV}$ in E.M unit,National Center For Radiation Research and Technology (NCRRT),Atomic Energy Authorty (AEA).

\section{Statistical analysis:}

Experimental data were analyzed using one way analysis of variance (ANOVA) using SPSS (statistical package for social sciences, 1999; ver.10.0), and the significance among the samples was compared at $\mathrm{P} \leq 0.05$. Results were represented as mean $\pm \mathrm{SE}(\mathrm{n}=8)$. 


\section{Results}

In the present study, the fractionated $\gamma$-irradiation ( $8 \mathrm{~Gy}$ ) induced a significant decrease in GSH level concomitant with a significant decrease in GPx, SOD and CAT activities, compared to that of control group. As shown in Table (1), oral administration with PJ before and during irradiation reduced the enzymatic activities of (GPx, SOD and CAT) and GSH value compared to irradiated group (Table 1).

Table I: The effect of pomegranate fruit juice on glutathione peroxidase, catalase and superoxide dismutase activities and glutathione content in the ileum of rats one day after exposure to 2Gy/week up to $8 \mathrm{~Gy} \gamma$-radiation.

\begin{tabular}{lllll}
\hline Animal groups & $\begin{array}{l}\text { GPx }(\mu \mathrm{g} \text { of } \mathrm{GSH} \\
\text { consumed/ } \\
\text { protein) }\end{array}$ & $\begin{array}{l}\mathrm{CAT}(\mu \mathrm{M} / \mathrm{g} \\
\text { protein })\end{array}$ & $\begin{array}{l}\mathrm{SOD}(\mu \mathrm{g} / \mathrm{g} \\
\text { protein) }\end{array}$ & $\begin{array}{l}\mathrm{GSH}(\mu \mathrm{g} / \mathrm{g} \\
\text { protein })\end{array}$ \\
\hline Control & $48 \pm 2.6^{\mathrm{ac}}$ & $18 \pm 1.2$ & $33 \pm 2.1$ & $25 \pm 1.8$ \\
PJ & $62 \pm 2.1^{\mathrm{ac}}$ & $20 \pm 1.4$ & $35 \pm 1.2^{\mathrm{c}}$ & $39 \pm 1.6^{\mathrm{ac}}$ \\
Irradiation & $40 \pm 2.3^{\mathrm{b}}$ & $13 \pm 0.6^{\mathrm{ab}}$ & $28 \pm 2.2^{\mathrm{b}}$ & $21 \pm 2.1^{\mathrm{ab}}$ \\
PJ+Irradiation & $45 \pm 3.8^{\mathrm{c}}$ & $19 \pm 1.4^{\mathrm{c}}$ & $41 \pm 2.1^{\mathrm{ac}}$ & $33 \pm 1.2^{\mathrm{abc}}$ \\
\hline
\end{tabular}

Values are expressed as means \pm Standard Error $(n=8)$

${ }^{a}$ Significant when compared with the control group. ${ }^{\text {b }}$ Significant when compared with the PJ group. ${ }^{\mathrm{c}}$ Significant when compared with the irradiated group..

Whole body gamma irradiation of rats provoked oxidative stress demonstrated by a significant increase of TBARS, CO and AOPP levels, compared to their respective values of control group. Oral administration with PJ has significantly attenuated the severity of radiation-induced oxidative stress, revealed a significant decrease in the oxidative stress biomarkers level.

Table II: The effect of pomegranate fruit juice on malondialdehyde, protein carbonyl and advanced oxidation protein products levels in the ileum of rats one day after exposure to $2 \mathrm{~Gy} /$ week up to $8 \mathrm{~Gy} \gamma$-irradiation.

\begin{tabular}{llll}
\hline Animal groups & $\begin{array}{l}\text { MDA } \\
(\mu \mathrm{M} / \mathrm{g} \text { protein })\end{array}$ & $\begin{array}{l}\mathrm{CO} \\
(\mu \mathrm{M} / \mathrm{g} \text { protein })\end{array}$ & $\begin{array}{l}\text { AOPP } \\
(\mu \mathrm{M} / \mathrm{g} \text { protein })\end{array}$ \\
\hline Control & $16 \pm 1.2$ & $14 \pm 1.3$ & $61 \pm 2.2$ \\
PJ & $14 \pm 1.2$ & $14 \pm 1.2$ & $57 \pm 2.9$ \\
Irradiation & $23 \pm 1.2^{\mathrm{ab}}$ & $20 \pm 1.6^{\mathrm{ab}}$ & $71 \pm 2.4^{\mathrm{ab}}$ \\
PJ+Irradiation & $17 \pm 1.0^{\mathrm{c}}$ & $16 \pm 1.1 \mathrm{c}$ & $65 \pm 2.9^{\mathrm{bc}}$ \\
\hline
\end{tabular}

*Legends as in table 1

Whole body gamma irradiation of rats significantly elevated TNF- $\alpha$ value in the ileum. The oral administration of animals with PJ markedly reduced TNF- $\alpha$ level as compared with control group. The oral administration of animals with PJ before and during irradiation has significantly ameliorated TNF- $\alpha$ level in the irradiated group compared to control.

Table III: The effect of pomegranate fruit juice (PJ) on TNF- $\alpha$ level in the ileum of rats one day after exposure to $2 \mathrm{~Gy} /$ week up to $8 \mathrm{~Gy} \gamma$-irradiation

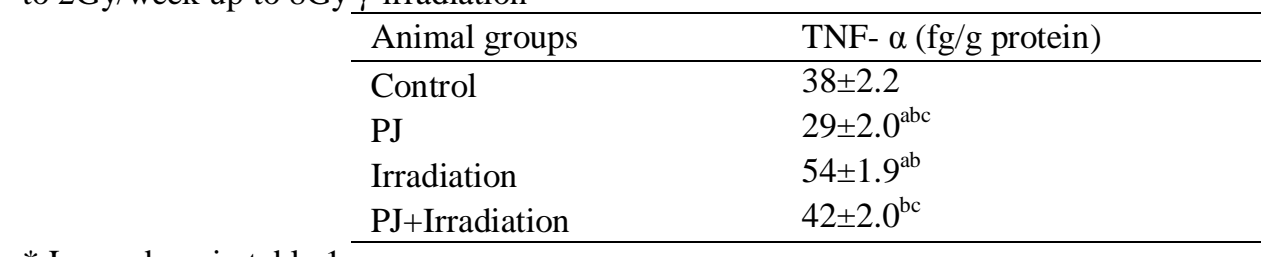

\section{* Legends as in table 1}

It is evident from Table (IV) that, irradiation of rats significantly increased apoptotic cell percentage and cell population at $S$ phase and $G_{2} / M$ phase compare to control, which is equivalent to cell cycle arrest at $S$ and $\mathrm{G}_{2}$ phases. In addition, the oral administration of animals with PJ markedly reduced cell population at $\mathrm{Go} / \mathrm{G}_{1}$ and increased cell population at $\mathrm{S}$ and $\mathrm{G}_{2}$ phases, while the oral administration of animals with PJ before and during irradiation has significantly ameliorated the apoptotic cell population percentage and significantly reduced cell population at $\mathrm{Go} / \mathrm{G}_{1}, \mathrm{~S}$ and $\mathrm{G}_{2} / \mathrm{M}$ phases. We might say that, PJ diminished cell cycle arrest at any phase in irradiated rats. 
Table IV: The effect of pomegranate fruit juice (PJ) on apoptosis and cell cycle analysis in the ileum of rats one day after exposure to $2 \mathrm{~Gy} /$ week up to $8 \mathrm{~Gy} \gamma$-irradiation.

\begin{tabular}{lllll}
\hline Animal groups & subG $_{1}(\%)$ & $\mathrm{Go} / \mathrm{G}_{1}(\%)$ & $\mathrm{S}(\%)$ & $\mathrm{G}_{2} / \mathrm{M}(\%)$ \\
\hline Control & $25 \pm 1.6$ & $32 \pm 1.3$ & $4 \pm 0.2$ & $3 \pm 0.1$ \\
PJ & $27 \pm 1.8^{\mathrm{ac}}$ & $19 \pm 0.6^{\mathrm{ac}}$ & $9 \pm 0.1^{\mathrm{ab}}$ & $4 \pm 0.1^{\mathrm{ac}}$ \\
Irradiation & $59 \pm 1.8^{\mathrm{ab}}$ & $25 \pm 1.5^{\mathrm{ab}}$ & $6 \pm 0.2^{\mathrm{ab}}$ & $2.5 \pm 0.2^{\mathrm{ab}}$ \\
PJ+irradiation & $32 \pm 1.6^{\mathrm{bc}}$ & $13 \pm 0.7^{\mathrm{abc}}$ & $3 \pm 0.2^{\mathrm{abc}}$ & $1 \pm 0.1^{\mathrm{abc}}$ \\
\hline
\end{tabular}

*Legends as in table 1

Ultra structural study by TEM (fig.1) showed that, Paneth cells are distinguished by the secretory granules that fill the upper third of the cell. The nucleus is irregular in outline and the nucleolus is a dense sponge-like reticulum and rod-shaped mitochondria are scattered below the nucleus of the cell (fig.1.a). Oral administration of PJ to rats for 28 days revealed that the Paneth's cells are normally present, residing at the base of the crypts(fig.1.b).

Ileums of irradiated rats showed sever damaged ileum with abnormal cell structure and high number of apoptotic cells. Damaged cell wall allowed the intrusion of bacterial cell from ileum into damaged Paneth cells (fig.1.c\&d). Rats supplemented with PJ before and during irradiation showed crypts containing surviving clonogenic cells reform with a lumen, Paneth cells at the base and numerous dividing cells. The majority of the Paneth cells appeared having normal organelles with few vacuoles, normal nuclei, nearly normal mitochondria and electron-dense secretary granules. Pre-secretory granules within electron-dense structures Paneth cells in the intestinal crypts surrounded by an electron-lucent "halo"(fig.1.e).
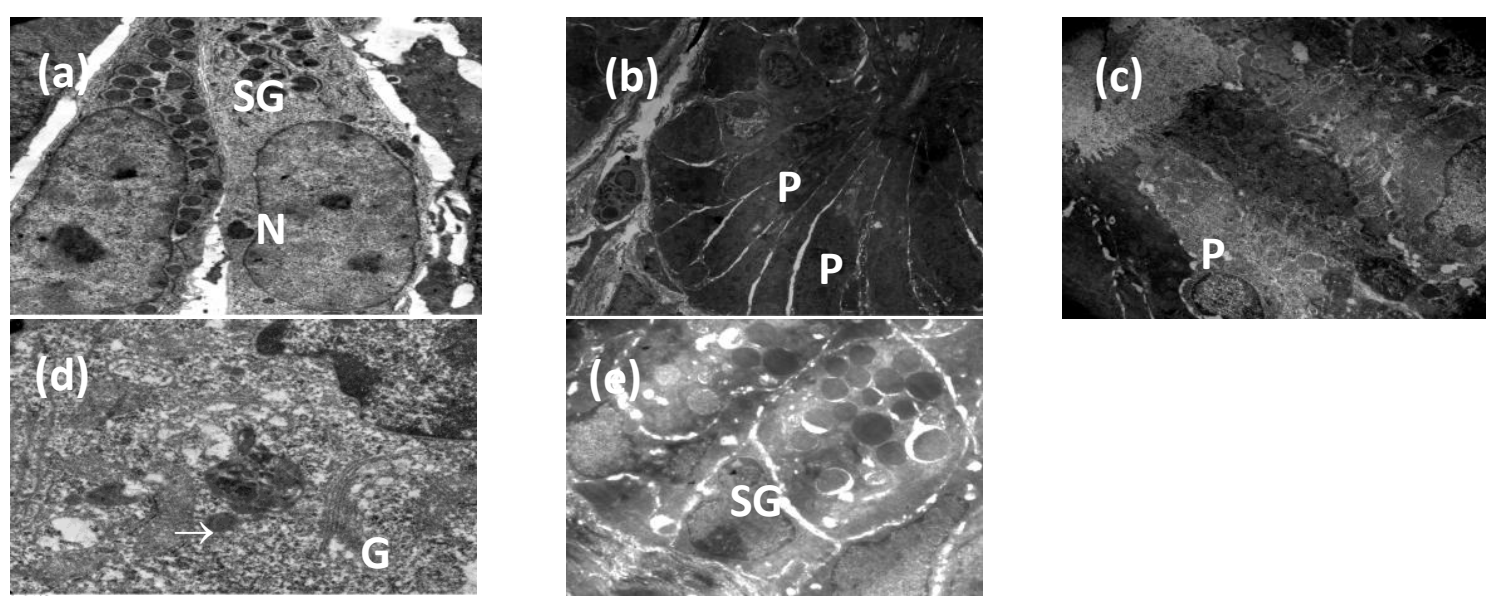

Fig.(1):Elect $t^{\prime}$ n micrograph of rats ileum showing: In control group (a) two Paneth cells distinguished by electron-dense secretory granules (SG), irregular nucleus $(\mathrm{N})$, and darker cytoplasm. (b) In PJ treated group: no ultrastructural changes in the intestinal crypts,(P) Paneth cells, (L) lumen. (c) In irradiated group: abnormal Paneth cells morphology, degranulation and apoptotic cells. (d) In irradiated group: Bacterial intrusions (arrow)into the lysosomes (Ly) of Paneth cells and Golgi apparatus (G). (e) In PJ+ irradiation group: amelioration in the intestinal crypts cells, Paneth cells healthy with electron-dense granules surrounded by an electron-lucent "halo".

\section{Dicussion}

Exposure of mammals to ionizing radiations oxidative stress was postulated as one of the mechanisms of radiation toxicity leads to the development of a complex, dose-dependent series of changes including changes in the structure and function of cellular components and organs damage (31). Radiation produced marked intestinal mucosal injury, a decrease in the number of villi, villus height, crypts cells, and damage of epithelial and goblet cells (32), regulation of macroautophagy and the presence of extensive granularity in Paneth cell of irradiated ileum (33). Experimental evidence has considered the small intestine a radiosensitive organ is the organ with the fastest cell turnover in the body. In the murine small intestine, the epithelium renews every 5 days (6\&34).

In the present study, whole body exposure of male albino rats to gamma radiation (8Gy fractionated) has provoked a decrease in the ileum 'antioxidant reserve' manifested by a significant decreases in (antioxidant 
enzymes) SOD, GPx and CAT activities and GSH content accompanied with an increase in the level of (oxidant stress markers) TBARS, $\mathrm{CO}$ and AOPP. The increase of TBARS level is probably due to the interaction of ${ }^{\circ} \mathrm{OH}$ resulting as a bi-product of water radiolysis, upon exposure to ionizing radiation, with the polyunsaturated fatty acids present in the phospholipids portion of cellular membranes (1).

In the same way, increase of $\mathrm{CO}$ and AOPP levels might be attributed to the interaction of proteins with ROS (35). Under oxidative stress as gamma irradiation, ROS production is able to overwhelm the scavenging systems, increasing the levels of lipid peroxidation and functionally impaired proteins (36). The decrease of SOD and CAT activities and GSH content in the present study was also reported (37) as whole body gamma rays induced a decrease in SOD, GPx and CAT activities and GSH content. GSH is a defense mechanism against increased production of free radicals resulting in the formation of thiyl radicals that associate to produce oxidized glutathione. The biological systems have an effective and complicated network of defense mechanisms for regulation of ROS concentrations (38). It could be accomplished by several enzymatic and nonenzymatic mechanisms. The enzymes responsible for controlling the tissue levels of $\mathrm{O}_{2}{ }^{-}$and $\mathrm{H}_{2} \mathrm{O}_{2}$ involve antioxidant enzymes, such as SOD, which catalyzes the dismutation of $\mathrm{O}_{2}$ 'to $\mathrm{H}_{2} \mathrm{O}_{2}$ and $\mathrm{O}_{2}$, CAT and peroxidases, which remove hydrogen peroxide and hydroperoxides. These enzymes normally act as a team, and thus SOD protects CAT and peroxidases against inhibition by $\mathrm{O}_{2}{ }^{*}$, whereas CAT and peroxidase provide protection for SOD against inactivation by hydrogen peroxide (39).

It is well documented, that antioxidants play an important role in ameliorating the damaging effects of oxidative stress on cells. According to the results obtained in the current study, oral administration of PJ before and during irradiation normalized antioxidant enzymes of GPx, CAT and SOD activities and GSH level and also normalized stress markers of MDA, CO and AOPP levels of the ileum tissues. This could be attributed to potent antioxidant activity and free radical scavenging capability of PJ due to its high content of polyphenols and flavonoids (40), also antinflammatory effect reducing TNF- $\alpha$ level (41). The results support the role of PJ in scavenging free radicals and antioxidant properties (42).

Intestinal Paneth-cells produce anti-microbial molecules and pro-inflammatory TNF- $\alpha$ which thought to generate ROS and activate the apoptosis signal TNF- $\alpha /$ ROS-induced intestinal epithelial cell injury, TNF- $\alpha$ induces mitochondrial autophagy via increased production of mtROS (43). In the present study a significant increase in TNF- $\alpha$ level in irradiated rats may play a role in increasing the effect of irradiation, since TNF- $\alpha$ deficient mice were partially protected from the apoptotic effects of irradiation. TNF- $\alpha$ may serve as the innate defense mechanism against radiation by restricting oxidative damage (44\&45).

In the present study, it is evident that irradiation of male rats by a fractionated dose of 8 Gy revealed arresting of ileum cell population at S and G2 phase and increase apoptotic cells at (subG1) compared to control rats. As a result of gamma irradiation, the proliferative activity in the crypts of the small intestine changes with fall in the mitotic index which soon start recovery and regeneration in the lower regions of the crypt with cyclic fluctuations to reach control level within $50 \mathrm{hrs}$ (46). A significant increase in AOPP is not only a marker of oxidative stress but also act as inflammatory mediators, since AOPPs trigger the inflammatory response by causing activation of nuclear factor NF- $\mathrm{kB}$ to induce apoptosis. PJ suppressed the powerful induction of NF- $\mathrm{KB}$ promoter which reduces apoptosis (47). Apoptotic cells are normally observed at the tips of villi as well as in crypts, in some inflammatory conditions, the number of apoptotic nuclei is reported to be enhanced in villus epithelial cells, indicating that apoptosis plays important roles not only in physiological replacement of villus epithelial cells but also in pathological conditions (48).

Ultrastructural study by TEM was important to study abnormal dissolution of post-secretory antimicrobial peptide granules which compromises innate host defense against enteric colonization with pathogenic bacteria (49). The intestinal microflora is involved in the pathogenesis both directly and indirectly. . Indirectly, the intestinal microflora is associated by stimulating mitotic activity in crypts, therefore more cells are in the radiosensitive phase. In germ-free animals there is a significant decrease in mitotic activity of crypts, and the migration time of epithelial cells from crypts to the apex villi is twice more prolongated, what induces possible restoration of active center after the irradiation. In the absence of microflora, the survival is greater in duration (50).

In the present study, the ultrastrucutal observations indicate that whole body irradiation with fractionated $\gamma$-radiation ( $8 \mathrm{~Gy}$ ) caused severe injury in Paneth cells, induced apoptosis and autophagy, bacteria invasion in the crypt of lumens. Apoptosis can be expected to occur flowing irradiation injury and play a role in inducing autophagy. Paneth cell secretory activity was observed at the sites of bacterial translocation in the crypt lumens. These data suggest that Paneth cells can contribute to small intestine inflammatory remodeling during the post-irradiation period $(12 \& 51)$.

In the current study TEM photos showed that, oral administration of PJ before and during irradiation had ameliorative effects against radiation injury in Paneth cell and the absence of bacterial invasion in the ileum. It has been shown that PJ has great efficiency as antimicrobial, anti-inflammatory and inhibiting microbial adherence (17). The ameliorative effects of PJ upon the ultrastructural alterations could be explained by the role 
of $\mathrm{PJ}$ in regulating vital cellular functions, including cell proliferation and differentiation and its potent antioxidant activity and free radical scavenging capability. Antimicrobial activity of pomegranate extracts, where the growth of Staphylococcus aureus, Streptococcus pyogenes, Diplococcus pneumoniae, Escherichia coli $\mathrm{O} 157: \mathrm{H} 7$, and Candida albicans was inhibited via direct bactericidal or fungicidal activity (52).

Based on the results obtained, it appears that, PJ attenuate the severity of ultrastructural alterations and preserve the integrity and function of Paneth cells and ameliorated biochemical disorders in ileum tissues mainly attributed to its high free radical scavenging and antioxidant properties.

\section{References:}

[1] Spitz, D.R.; Azzam, E.I.; Li, J.J. and Gius, D. (2004): Metabolic oxidation/reduction reactions and cellular responses to ionizing radiation: a unifying concept in stress response biology. Cancer Metastasis Rev. 23: 311 .

[2] Frisby, C.; Fraser, R.; Schirmer, M.; Yeoh, E. and Blackshaw, L. (2007): Roles of muscarinic receptor subtypes in small intestinal motor dysfunction in acute radiation enteritis. Am J Physiol Gastroint Liver Physiol. 293(1): 121.

[3] El-Tahawy, N.A. (2009): Curcumin attenuates gamma radiation induced intestinal damage in rats. Egpt J Rad Sci Applic. 22 (1): 7.

[4] Baglole, C.J.; Davison, J.S. and Meddings, J.B. (2005): Epithelial distribution of neural receptors in the guinea pig small intestine. Can J Physiol Pharm. 83: 389.

[5] Saada, H. N.; Renée, G.R. and El-Tahawy, N.A. (2010): Lycopene Protects the Structure of the Small Intestine against GammaRadiation-induced Oxidative Stress. Phytother. Res. 24: S204.

[6] Somosy, Z.; Horvath,G.; Telbisz, A.; Rez, G. and Palfia, Z. (2002): Morphological aspects of ionizing radiation of small intestine. Micron. 33:167.

[7] Linard, C.R.; Ropenga, A.; Vozenin-Brotons, M.C.; Chaapel, A.and Mathe, D. (2003): Abdominal irradiation increases inflammatory cytokine expression and activates NF-kappab in rats ileal muscularis layer. Am J Physiol g gastrointestinal liver physiology; 285:G556.

[8] Madara, J.L. and Trier, J.S. (1987): Functional morphology of the mucosa of the small intestine. In: Physiology of the Gastrointestinal Tract ( $2^{\text {nd }}$ ed.), edited by Johnson LR. New York: Raven, pp. 1209.

[9] Ouellette, A.J.; Darmoul, D.; Tran, D.; Huttner, K.M.; Yuan, J. and Selsted, M. E. (1999): Peptide localization and gene structure of cryptdin 4, a differentially expressed mouse Paneth cell $\alpha$-defensin. Infect Immun. 67: 6643.

[10] Backhed, F.; Ding, H.; Wang, T.; Hooper, L.V.; Koh, G.Y.; Nagy, A.; Semenkovich, C.F. and Gordon, J.I. (2004): The gut microbiota as an environmental factor that regulates fat storage. Proc Natl Acad Sci U S A. 101: 15718.

[11] HOOPER, L.V.; MIDTVEDT, T. and GORDON, J.I. (2002): How host-microbial interactions shape the nutrient environment of the mammalian intestine. Annu Rev Nutr. 22: 283.

[12] Gorbunov, N.V.; Garrison, B.R. and Kiang, J.G. (2010): Response of crypt paneth cells in the small intestine following total body $\gamma$-irradiation. Int J Immunopathol Pharmacol, 23(4):1111.

[13] Gil, M.I.; Tomás-Barberán, F.A.; Hess-Pierce, B.; Holcroft, D.M. and Kader, A.A. (2000): Antioxidant activity of pomegranate juice and its relationship with phenolic composition and processing. J Agric Food Chem.48: 4581.

[14] Festa, F.; Aglitti, T.; Duranti, G.; Ricordy, R; Perticone P. and Cozzi, R. (2001): Strong antioxidant activity of ellagic acid in mammalian cells in vitro revealed by the comet assay. Anticancer Research, 21: 3903.

[15] Narr Ben, C.; Ayed N. and Metche M. (1996): Quantitative determination of the polyphenolic content of pomegranate peel. Zeitschrift für Lebensmittel-Untersuchung und-Forschung. 203: 374.

[16] Akiyama, H.; Fujii, K.; Yamasaki, O.; Oono, T. and Iwatsuki, K. (2001): Antibacterial action of several tannins against Staphylococcus aureus. J Antimicrob Chemother, 48: 487.

[17] Duman, A.D.; Ozgen, M.; Dayisoylu, K.S.; Erbil, N. and Durgac, C. (2009): Antimicrobial activity of six pomegranate (Punica granatum L.) varietie and their relation to some of their pomological and phytonutrient characteristics. Molecules, 13(14): 1808.

[18] Thresiamma, K.C. and Kuttan R. (1996) :Inhibition of liver fibrosis by ellagic acid. Indian J Physiol Pharmacol, 40: 363.

[19] Turk G, Sonmez M, Aydin M, Yuce A, Gur S, Yuksel M, Aksu EH, Aksoy H (2008). Effects of pomegranate juice consumption on sperm quality, spermatogenic cell density, antioxidant activity and testosterone level in male rats. Clin Nutr., 27: 289-296.

[20] Paglia, D.E. and Valentine, W.N. (1967): Studies on the quantitative and qualitative characterization of erythrocyte glutathione peroxidase. J Lab Clin Med, 70: 158.

[21] Minami, M. and Yoshikawa, M.A. (1979): A simplified assay method of super=oxide dismutase activity for clinical use. Clin. Chim. Acta., 92: 337.

[22] Aebi, H. (1984): Catalase in vitro. Methods Enzymol. 105: 12.

[23] 23-Beutler, E.; Duron, O. and Kelly, B. M. (1963): Improved method of the determination of blood glutathione. J. Lab. \& Clin. Med. 61 (5): 882.

[24] Yoshioka, T.; Kawada, K.; Shimada, T. and Mori, M. (1979): Lipid peroxidation in maternal and cord blood and protective mechanism against activated oxygen toxicity in the blood. Am. J. Obstet. Gynecol. 135:372.

[25] Lowry, O.H.; Rosebrough, N.J.; Farr, A.L. and Randall, R.J. (1951): Protein measurement with the folin phenol reagent. J Biol Chem; 193:265.

[26] Witko-Sarsat,V.; Friedlander, M.; Capelliere-Blandin, C.; Nguyen-Khoa, T.; Nguyen, A.T.; Zingraff, J.; Jungers, P. and Descamps-Latscha, B. (1996):Advanced oxidation protein products as a novel marker of oxidative stress in uremia. Kidney Int 49: 1304 .

[27] Levine, R. L.; Williams, J. A.; Stadtman, E. R. and Shacter, E. (1994): Carbonyl assays for determination of oxidatively modi fied proteins. Methods Enzymol. 233:346.

[28] Taylor, P.C. (2001): Anti-TNF therapy for rheumatoid arthritis and other inflammatory diseases. Mol Biotechnol. 19(2):153.

[29] 29-Dean, P. N. and Jett, J. H. (1974): Mathematical analysis of DNA distributions derived from flow microfluorometry. J Cell Biol. 60:523.

[30] Glauert, A. M. and Lewis, P. R. (1998): Biological Specimen Preparation for Transmission Electron Microscopy.Princeton University Press, pp.326.

[31] Finkel, T. and Holbrook, N.J. (2000): Oxidants, oxidative stress and the biology of ageing. Nature. 408: 239.

[32] Akpolat, M.; Kanter, M. and Uzal, M.C. (2009): Protective effects of curcumin against gamma radiation-induced ileal mucosal damage. Arch Toxicol, 83(6): 609.

[33] Gorbunov, N.V. and Kiang, J.G. (2009): Up-regulation of autophagy in small intestine Paneth cells in response to total-body gamma-irradiation. J Pathol. 219: 242. 
[34] Harfouche, G. and Martin, M.T. (2010): Response of normal stem cells to ionizing radiation: A balance between homeostasis and genomic stability. Mutat Res, 704:167.

[35] Meaney, E.; Vela, A.; Samaniego, V.; Meaney, A.; Asbún, J.; Zempoalteca, J.C.; Elisa, Z.N.; Emma, M.N.; Guzman, M.; Hicks, J. and Ceballos, G. (2008): Metformin, arterial function, intima-media thickness and nitroxidation in metabolic syndrome: the mefisto study. Clin Exp Pharmacol Physiol, 35:895.

[36] Fedorova, M.; Kuleva, N. and Hoffmann, R. (2010): Identification, quantification, and functional aspects of skeletal muscle protein-carbonylation in vivo during acute oxidative stress. J Proteome Res. 7; 9 (5):2516.

[37] Saada,H.N.; Rezk,R.G. and Eltahawy,N.A.(2010): Lycopene protects the structure of the small intestine against gamma radiation induced oxidative stress. Phytother.Res. 24(2):s204.

[38] Vučić,V.; Isenović, E.R.; Adžić, A.; Ruzdijić, S. and Radojčić, M.B. (2006): Effect of gamma radiation on cell growth, cycle arrest,death, and superoxide dismutase expression by DU 145 human prostate cancer cells. Braz J Med Biol Res. 39(2): 227.

[39] Lee, J.H.; Kim, S.K.; Kil, I.S. and Park1, J. (2007): Regulation of ionizing radiation-induced apoptosis by mitochondrial NADPdependent isocitrate dehydrogenase. J Biol Chem. 282(18): 13385.

[40] Aviram, M.; Dornfeld, L.; Kaplan, M.; Coleman, R.; Gaitini, D.; Nitecki, S.; Hofman, A.; Rosenblat, M.; Volkova, N.; Presser, D.; Attias, J.; Hayek, T. and Fuhrman, B. (2002). Pomegranate juice flavonoids inhibit low-density lipoprotein oxidation and cardiovascular diseases: studies in atherosclerotic mice and in humans. Drugs Exp Clin Res. 28(2-3):49.

[41] Rasheed, Z.; Akhtar, N.; Anbazhagan, A.N. Ramamurthy, S.Shukla M.and. Haqqi . T.M (2009): Polyphenol-rich pomegranate fruit extract (POMx) suppresses PMACI-induced expression of pro- inflammatory cytokines by inhibiting the activation of MAP Kinases and NF-kappaB in human KU812 cells. J Inflamm. 8(6): 1.

[42] Koyama, S.; Cobb, L. J.; Mehta, H.H.; Seeram, N.P.; Heber, D.; Pantuck, A.J. and Cohen, P., (2010): Pomegranate extract induces apoptosis in human prostate cancer cells by modulation of the IGF-IGFBP axis. Growth Horm IGF Res, $20: 55$.

[43] Baregamian, N.; Jun Song, J.C. ; Eric Bailey, E.; Papaconstantinou, J.; Evers, M. and Chung, D.H.(2009): Tumor necrosis fact or$\alpha$ and apoptosis signal-regulating kinase 1 control reactive oxygen species release, mitochondrial autophagy and c-Jun N-terminal kinase/p38 phosphorylation during necrotizing enterocolitis. Oxid Med Cell Longev, 2(5): 297

[44] Cachaco, A.S.; Carvalho, T.; Santos, A.C.; Igreja, C.; Fragoso, R.; et al. (2010): TNF-a regulates the effects of irradiation in the mouse bone marrow. Microenvironment. PLOS ONE. 5(2): e8980.

[45] Kim, N.D.; Mehta, R.; Yu, ; Neeman, I.; Livney, T.; Amichay, A.; Poirier, D.; Nicholls, P.; Kirby, A.; Jiang, W.; Mansel, R.; Ramachandran, C.; Rabi, T.; Kaplan, B. and Lansky, E. (2002): Chemopreventive and adjuvant therapeutic potential of pomegranate (Punica granatum) for human breast cancer. Breast Cancer Res Treat, 71: 203

[46] Potten,C.S. and Chadwick,C.A.(1994): Small intestinal growth regulatory factors extracted by simple diffusion from intact irradiated intestine and tested in vivo. Growth factors. 10(1):63-75.

[47] Zuwała-Jagiełło, J.; Pazgan-Simon, M.; Simon,K. and Warwas, M. (2011):Advanced oxidation protein products and inflammatory markers in liver cirrhosis: a comparison between alcohol-related and HCV-related cirrhosis. Acta Biochim Pol.58 (1):59.

[48] Hyoh,Y.; Ishizaka, S.; Horii T.; Fujiwara, A.; Tegoshi, T.; Yamada, M.; Arizono, N. (2002): Activation of caspases in intestinal villus epithelial cells of normal and nematode infected rats. Gut. 50:71.

[49] Ayabe, T.; Satchell, D.P.; Pesendorfer, P.; Tanabe, H.; Wilson, C.L.; Hagen, S.J.; and Ouellette, A.J. (2002): Activation of Paneth cell $\alpha$-defensins in mouse small intestine. J Biol Chem., 277: 5219.

[50] Mandel,L and Svoboda,V.(1991): The gastrointestinal post-irradiation syndrome. Sb Ved Pr Lek Fak Karlovy Univerzity Hradci Kralove Suppl. 34(4):477.

[51] Juliann, G. K.; Garrison, B. R. and. Gorbunov, N.V. (2010): Radiation Combined Injury: DNA Damage; Apoptosis and Autophagy. adptive Medicine. 2(1): 1 .

[52] Julie, J. M.T. (2008): Therapeutic Applications of Pomegranate (Punica granatum L.): A Review. Alternative Medicine Review. 13(2):128. 